AGNIESZKA PALION-MUSIOE

\title{
NAUCZANIE GRAMATYKI I LEKSYKI POPRZEZ SZTUKE. EKFRAZA, INFRAZA I AUDIODESKRYPCJA NA LEKCJI JEZZYKA OBCEGO
}

\author{
WPROWADZENIE
}

Ekfraza, infraza i audiodeskrypcja należą do przekładu intersemiotycznego, którego celem jest transpozycja i odtworzenie znaku w innym systemie, co wiąże się z interpretacją i pewną transformacją tego znaku. Zdaniem Seweryny Wysłouch, strukturalna wspólnota sztuk pozwala na przeniesienie sensów z jednego medium do innego oraz „przeprowadzeniu tych samych operacji, wykonywanych $\mathrm{w}$ innym materiale: $\mathrm{w}$ języku, na płótnie czy ekranie" (23). Strukturalna zatem wspólnota sztuk to przeniesienie pewnego oglądu obiektu referencyjnego, sposobu myślenia o nim, który nie jest ograniczony poprzez medium. Celem artykułu jest wykorzystanie tekstu malarskiego czy literackiego, posiadających własne formy wyrazu, i stworzenie z nich narzędzia dydaktycznego, które ma służyć atrakcyjnemu i skutecznemu przyswojeniu i zapamiętaniu struktur leksykalnych i gramatycznych na lekcji lub lektoracie języka obcego.

Zaproponowane ćwiczenia mogą być modyfikowane przez nauczyciela w zależności od poziomu znajomości języka obcego przez ucznia oraz wyznaczonych celów dydaktycznych. Ćwiczenia mogą być zastosowane niezależnie od nauczanego języka.

Dr Agnieszka Palion-Musiol - Akademia Techniczno-Humanistyczna w Bielsku-Białej, Wydział Humanistyczno-Społeczny, Instytut Neofilologii; e-mail: apalion@ath.bielsko.pl; ORCID: 0000-0003-4244-7866. 


\section{PRZEKŁAD INTERSEMIOTYCZNY JAKO METODA DYDAKTYCZNA}

Roman Jakobson, w publikacji $O$ językoznawczych aspektach przektadu (1959 [2009]), jako pierwszy dokonał triadycznego podziału przekładu na przekład międzyjęzykowy, wewnątrzjęzykowy oraz intersemiotyczny. Przekład intersemiotyczny zakłada przeniesienie sensów wyrażonych $\mathrm{w}$ jednym systemie znakowym, na przykład werbalnym, na znaki innego systemu, który mogą stanowić płótno malarskie, utwór muzyczny czy taniec (por. Jakobson 44, 49). Umiejętność odkodowywania i przekładania jednych systemów semiotycznych na inne Hartmut. Stöckl określa multimodalnością komunikacji rozumianą jako

ogólnokulturową kompetencję $\mathrm{i}$ indywidualną inteligencję, polegającą na rozkodowaniu przez „transkrybowanie”, tzn. komentowanie, wyjaśnianie lub parafrazowanie treści przekazywanych przez jeden system za pomocą innych systemów znaków. (Cyt. za: Opiłkowski, Jarosz i Staniewski 115)

(...) Multisensoryczne uwarunkowanie człowieka wymusza komunikację multimodalną. (Cyt. za: Opiłkowski, Jarosz i Staniewski 116)

Zgodnie z propozycją Stöckla obrazy służą w komunikacji jako obiekty, które są opisywane i poprzez tekst narracyjny reprezentowane i uobecniane w innym znaku, jak ma to miejsce w audiodeskrypcji lub ekfrazie, ale także te same obrazy mogą być rozpatrywane jako artefakty komunikacyjne, będące wytworem ucznia inspirowanym lekturą, co będę starała się pokazać poprzez wykorzystanie infrazy na lekcji języka obcego.

Anna Dyduchowa, pisząc o roli obrazu w dydaktyce kształcenia językowego, odwoływała się do badań psychologicznych ukazujących pozytywny jego wpływ na uczenie się leksyki oraz traktowała obraz jako podstawę ćwiczeń rozwijających kompetencje ustne i pisemne (zob. Dyduchowa 98). Praca z obrazem, jako środkiem i sposobem działań dydaktycznych, wymaga zrozumienia złożonych płaszczyzn opisu dzieła malarskiego, które obejmują semiotykę stanowiącą funkcjonowanie obrazów jako znaków, percepcję i kognitywne przetwarzanie obrazów, semantykę ukazującą potencjał znaczeniowy oraz pragmatykę utożsamioną z funkcjami komunikacyjnymi, jakie obraz może realizować (Stöckl za: Opiłkowski, Jarosz i Staniewski 116).

Obraz i język operują odmiennymi środkami wyrazu, o czym pisał Stöckl (za: Opiłkowski, Jarosz i Staniewski 116-117). Płótno malarskie wymaga od oglądającego wiedzy o przedstawionych wydarzeniach, sytuacjach lub 
obiektach. Zakłada wiedzę pozajęzykową odbiorcy, która aktywuje się w kontakcie z dziełem. Brak kombinatoryki gramatycznej charakteryzujący obraz nie jest przeszkodą do odczytania przekazu płynącego z płótna, gdyż oglądający, dzięki posiadanej wiedzy, potrafi odczytać potencjał semiotyczny obrazu. W tym odczytaniu z pomocą przychodzi tytuł dzieła, rama czasowa jego powstania oraz styl, do którego należy, czy tekst towarzyszący obrazowi, a także indywidualne doświadczenia. W tym miejscu należy zwrócić uwagę, że obraz jest w odbiorze rodzajem szybkiego tekstu, gdyż integruje wszystkie elementy i przedstawia je w sposób całościowy. Złożony jednak i bogaty charakter semantyczny obrazu, który przejawia się w stylu i gatunku, kolorystyce, formacie, ostrości, konturze, formie, wpływa na odbiór i postrzeganie tego wizualnego tekstu, a tym samym na jego niejednoznaczność $^{1}$. Te same właściwości semiotyczne i semantyczne znaku wiążą się z funkcją estetyczną sztuki, a także wpływają na emocje i odczucia w kontakcie z dziełem. Werner Kroeber-Riel podkreśla moc oddziaływania obrazów na wyobraźnię odbiorcy, powołując się przy tym na badania psychologiczne, które wykazały łatwość zapamiętywania i odtwarzania $\mathrm{z}$ pamięci tych form wyrazu artystycznego u odbiorcy (por. Kroeber-Riel, 53). Pracując z obrazem, uczeń musi odgadnąć i nazwać relacje przyczynowo-skutkowe na obrazie, relacje odbywające się sekwencyjnie w czasie, intencję autora i przedstawionych postaci, kontekst historyczny i kulturowy przedstawienia, intertekstualne odniesienia zawarte $\mathrm{w}$ obrazie oraz powinien być wrażliwym na funkcję estetyczną obrazu². Wymienione poziomy opisu pozwolą wyjść uczniowi poza deskrypcję elementów widocznych na obrazie oraz zrealizować cel przekładu, który nie jest ograniczony przez materię, zgodnie z ideą przenoszenia sensów, a nie znaków. To dzięki świadomości struktur opisowych uczeń nauczy się łączyć poszczególne elementy w jedną całość przedstawioną na obrazie. Dlatego też ważne jest, aby na zajęciach językowych

uczyć wprowadzenia słownej narracji scalającej obraz poprzez różnorodne ćwiczenia słownikowe, składniowe, itp., tak konstruowane, aby mogły również między innymi kształcić emotywną funkcję języka na podstawie funkcji emotywnej komunikatu, jakim jest dzieło malarskie. (Dyduchowa 99)

Działania dydaktyczne podjęte przez nauczyciela języka obcego pracującego z przekładem intersemiotycznym muszą być celowe i przemyślane,

\footnotetext{
${ }^{1}$ Por. Stöckl w Opiłkowski, Jarosz i Staniewski 116-118.

${ }^{2} \mathrm{O}$ narracyjnym charakterze pojedynczych obrazów pisze Klaus Speidel (w Kaczmarczyk 65-148).
} 
a ich struktura obejmuje trzy etapy działań ucznia: obserwację obrazu, ćwiczenia językowe oraz redakcję opisu płaszczyzny wizualnej (Dyduchowa 100). Zaproponowane dalej ćwiczenia łączą każdy z etapów działań ucznia poprzez obserwację obrazu, analizuje i interpretuje dzieło, używając do tego często specjalistycznej leksyki i struktur służących nazwaniu treści i elementów przedstawionych, relacji przestrzennych, perspektywy, faktury, wykorzystanej techniki czy symboliki barw i obiektów. Na kolejnym etapie pracy z obrazem uczeń werbalizuje swoje emocje, odczucia i skojarzenia z dziełem, czyli dokonuje jego oceny. Często sięga po wyrażenia i leksykę związaną ze sferą emocjonalną człowieka, a także metafory i porównania. Redagowanie opisu dzieła sztuki ma formę połączenia i wykorzystania wszystkich ćwiczeń językowych praktykowanych na wcześniejszych etapach pracy z obrazem lub dziełem literackim, ale też pozwala na uświadomienie uczniowi różnic między gatunkami wypowiedzi, takimi jak recenzja, streszczenie, opis czy właśnie tekst narracyjny w formie przekładu intersemiotycznego.

Opisana struktura działań dydaktycznych będzie wystarczająca w ćwiczeniach $\mathrm{z}$ ekfrazą, natomiast $\mathrm{w}$ przypadku audiodeskrypcji musi być bardziej rozbudowana. W tym ostatnim przypadku proponujemy projektowanie działań ucznia według schematu: obserwacja obrazu, ćwiczenia językowe, przygotowanie skryptu narracyjnego oraz jego nagranie. Ćwiczenia wykorzystujące infrazę jako środek dydaktyczny wymagają innej struktury ze względu na odmienny charakter podejmowanych działań. W tym wypadku działania dydaktyczne rozpoczynają się od lektury tekstu, ćwiczeń językowych skupionych na interpretacji i emocjach wywołanych lekturą, reprezentacji graficznej tekstu oraz redakcji opisu do stworzonej w wyniku lektury tekstu infrazy. Zadania ucznia obejmują zatem lekturę tekstu wizualnego lub literackiego, ćwiczenia językowe przygotowujące do przekładu, przekład intersemiotyczny, polegający na przekodowaniu jednego kodu (wizualnego lub językowego) w drugi, a następnie wypowiedź pisemną lub ustną na temat przekładu ${ }^{3}$.

Metoda przekładu intersemiotycznego wykorzystywana w celach dydaktycznych na lekcji językowej pozwala kształcić nie tylko sprawności językowe, ale też pobudza ucznia do kreatywnego używania języka na poziomie codziennej komunikacji. To ważna kompetencja, zwłaszcza w sytuacji, gdy uczeń musi konstruować wypowiedzi o charakterze interpretacyjnym, analitycznym lub użyć języka w sposób kreatywny.

\footnotetext{
${ }^{3}$ Eugeniusz Szymik w swoim artykule „Metoda przekładu intersemiotycznego w edukacji wczesnoszkolnej” omawia wykorzystanie przekładu intersemiotycznego w formie dramy w edukacji polonistycznej.
} 


\section{KRÓTKA CHARAKTERYSTYKA AUDIODESKRYPCJI, EKFRAZY I INFRAZY JAKO ŚRODKA DYDAKTYCZNEGO}

Audiodeskrypcja to technika narracyjna służąca udostępnieniu treści wizualnych osobom niewidomym i słabowidzącym. Jest „dodatkową ścieżką dźwiękową zawierającą opis informacji wizualnych”, „komentarzem wplecionym w ścieżkę dźwiękową, wykorzystującym pauzy w dialogach, aby opisać to, co dzieje się na ekranie, postaci, miejsca, mimikę twarzy, język ciała, kostiumy i rekwizyty" (Chmiel i Mazur 19).

Audiodeskrypcja do dzieł sztuki ma autonomiczną formę i jest udostępniana w muzeach lub galeriach $\mathrm{w}$ postaci najczęściej trzyminutowego nagranego opisu dzieła odtwarzanego w audioprzewodniku lub w specjalniej aplikacji na telefon ${ }^{4}$.

Obowiązujące $\mathrm{w}$ audiodeskrypcji zasady, można zawrzeć w trzech punktach (za Szymańska i Strzymiński 14):

1. Opisz to, co widać na obrazie, co możesz na nim zaobserwować.

2. Nie interpretuj, nie przedstawiaj swoich wniosków, opinii ani motywów opisywanych postaci.

3. Nie mów w czasie dialogów. Wyjątek stanowią jedynie bardzo istotne akcje rozgrywające się na ich tle.

Audiodeskrypcja jako środek dydaktyczny sprzyja praktykowaniu umiejętności pisania, mówienia, czytania i rozumienia ze słuchu, składających się na kompetencję językową, oraz rozwijaniu kompetencji interkulturowej i wizualnej ${ }^{5}$. Pozwala wykorzystać materiały autentyczne i nowe technologie, które są atrakcyjne dla ucznia. Poprzez pracę w filmami, pozwala obserwować i ćwiczyć różne rejestry języka, wyrażenia i zwroty kolokwialne, a także leksykę specjalistyczną dotyczącą malarstwa i sztuki. Ze względu na duży potencjał audiodeskrypcji w dalszej części tekstu zostaną zawarte propozycje ćwiczeń, które mogą zostać wykorzystane na lekcji języka obcego.

Równie ciekawe możliwości dydaktyczne stwarza ekfraza, która jest utworem poetyckim reprezentującym dzieło sztuki. Stanowi opis dzieła malarskiego, rzeźby lub budowli, który nie służy do wiernego jej odtworzenia czy przedstawienia - jest interpretacją dzieła sztuki, subiektywną

${ }^{4} \mathrm{~W}$ celu zapoznania się z projektem OpenArt, proponuję tekst A. Szarkowskiej, A. Jankowskiej i K. Krejtza „Open Art. - desinging a multimedia guide app for people with and without sensory impairments".

${ }^{5} \mathrm{O}$ wykorzystaniu audiodeskrypcji w kształceniu językowym zob. Clouet; Ibáñez Moreno i Vermeulen, "La audiodescripción”, “Audio Description” i "Using audio description”; Gajek; Calduch i Talávan; Talávan. 
słowną reprezentacją, która z jednej strony służy zastąpieniu oryginalnego dzieła, a z drugiej - wskazaniu na nie. Substytucja, która ma miejsce w ekfrazie, służy ożywieniu i przywołaniu obiektu oryginalnego, stanowiąc tym samym samodzielny utwór, a zarazem wynik przekładu intersemiotycznego.

Adam Dziadek definiuje ekfrazę jako opis lub elementy opisu obrazu, który może odnosić się tak do dzieła rzeczywistego jak i fikcyjnego. Ekfraza może zawierać oznaki metatekstowe, którymi są bezpośrednie odniesienia do dzieła, takie jak: tytuł obrazu, nazwisko autora, styl, kierunek w sztuce, znany motyw, etc. (por. Dziadek 141-142). Jako przykłady można przywołać Lekcje anatomii (Rembrandta) Stanisława Grochowiaka, Dwie matpy Bruegla Wisławy Szymborskiej, Syna marnotrawnego (z obrazu Hieronima Boscha) Tadeusza Różewicza, Mona Lizę Zbigniewa Herberta, Płonaca zyrafe Stanisława Grochowiaka, Chagalla Joanny Kulmowej, Secesję Marii Pawlikowskiej-Jasnorzewskiej, Kobiety Rubensa Wisławy Szymborskiej czy Olejne jabłka Marii Pawlikowskiej-Jasnorzewskiej, nawiązujące do malarstwa Paula Cézanne'a.

Jako trzeci środek dydaktyczny zostanie omówiona infraza, która jest przeciwieństwem ekfrazy. Jest malarską reprezentacją tekstu literackiego, stanowiącą jego subiektywną interpretację, która zastępuje tekst literacki, a jednocześnie jest jej uobecnieniem zrealizowanym w znaku wizualnym. Ta nowa postać tekstu malarskiego służy wskazaniu i ożywieniu oryginału oraz poprzez swoją wizualną formę udostępnia naocznie treść tekstu literackiego, któremu jest ekwiwalentna. Prezentacja w infrazie polega na wskazaniu tekstu oryginalnego, a reprezentacja jest jego efektownym odtworzeniem malarskim, które czyni dostępnym wizualnie tekst pierwowzoru. Należy tu zwrócić uwagę, że tekst pierwowzoru jest również pewną reprezentacją rzeczywistości, którą opisuje, a zatem, uściślając, infraza jest malarską reprezentacją reprezentacji słownej, którą stanowi tekst oryginalny.

Teresa Radziewicz trafnie oddaje najważniejszą charakterystykę infrazy:

bez wątpliwości można powiedzieć, że tak jak celu ekfrazy nie stanowi werbalizowanie wyglądu dzieła malarskiego, lecz wyraz uniwersalnej emocji związanej z patrzeniem na obraz, tak celem infrazy nie jest ilustracja do tekstu, lecz zobrazowanie emocji wzbudzanej przez dzieło literackie. (167)

Dla zobrazowania emocji, którą wzbudziły wiersze Wandy Karczewskiej, prezentuję za T. Radziewicz infrazy wykonane przez K. Schodowskiego do powieści Odejście (Radziewicz 175-176): 

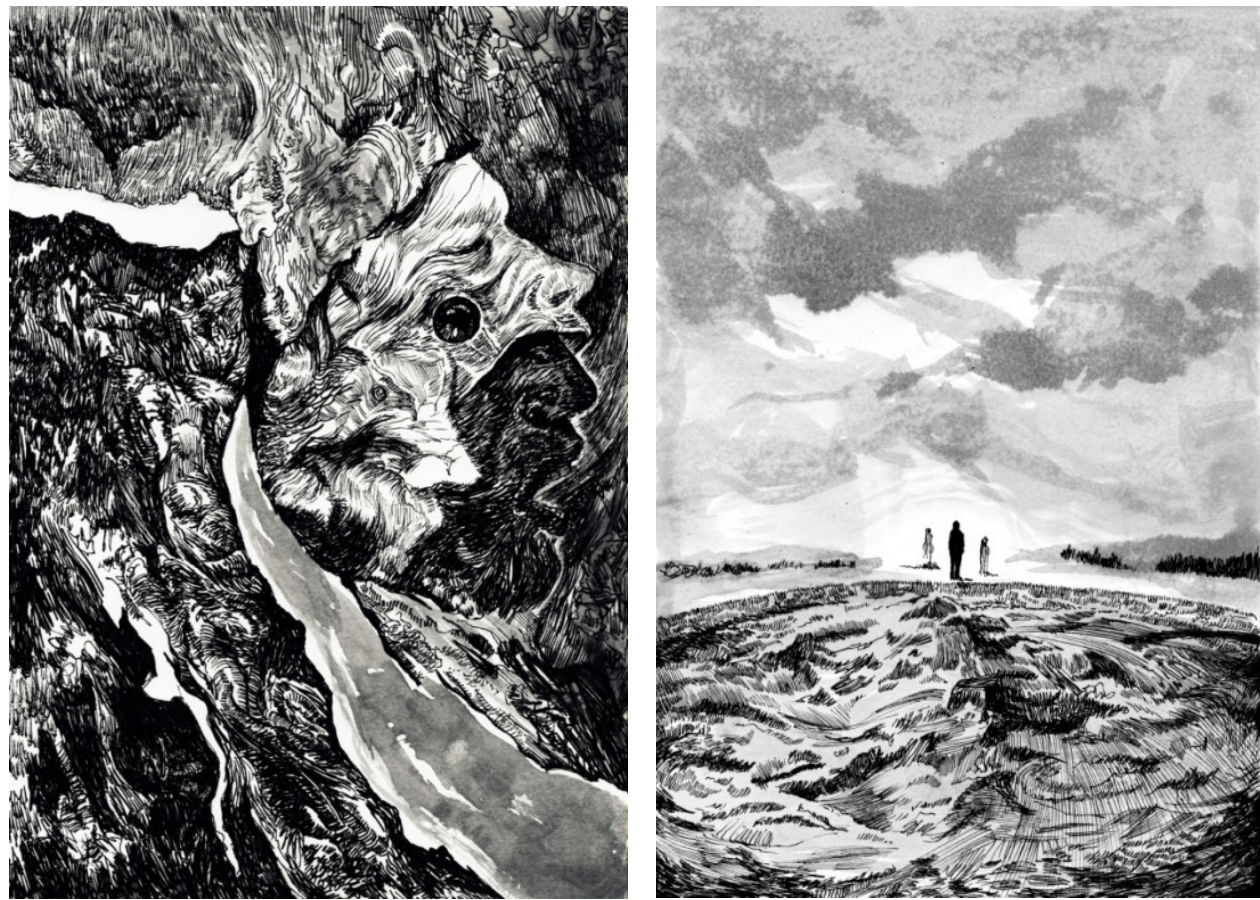

Infraza jest wynikiem interakcji czytelnika z tekstem. Lektura wywołuje w czytelniku silną emocję i staje się bodźcem do jej zmaterializowania i uobecnienia w postaci nowego tekstu malarskiego. W tym wypadku również czytelnik oddziałuje na tekst literacki poprzez stworzoną infrazę, która jako reprezentacja reprezentacji tekstu dopełnia intersemiotycznie dzieło i wraz z nim zaczyna tworzyć nowe, pełniejsze i wielosystemowe jego odczytanie.

\section{PRZYKŁADY WYKORZYSTANIA AUDIODESKRYPCJ, EKFRAZY I INFRAZY W EDUKACJI JEZZYKOWEJ}

Proponowany w tekście przekład intersemiotyczny, jako metoda dydaktyczna, nie powinien zastąpić innych metod oferowanych w glottodydaktyce. Powinien być urozmaiceniem i uzupełnieniem wybranej przez nauczyciela metody. Wybór konkretnych obrazów czy tekstów literackich jest uzależniony od indywidualnych potrzeb grupy, specyfiki kursu, celów, które wyznaczył nauczyciel, a także poziomu językowego. Bezpośredni wpływ na dobór materiału ma również tematyka zajęć, zagadnienia gramatyczne 
aktualnie omawiane czy wprowadzana leksyka ${ }^{6}$. Jako wskazówkę przy wyborze obrazów i tekstów literackich, warto zapamiętać następującą sugestię:

Dobrze dobrany obraz czy tekst literacki powinien dać możliwość przejścia od rozważań ściśle polskich, narodowych do kwestii uniwersalnych, ogólnoludzkich. Interpretacja tego rodzaju tekstów kultury powinna prowadzić do opisu rzeczywistości pozatekstowej, prowokować dyskusję, konfrontować różnorodność postaw. (Szałasta-Rogowska 144)

Zaproponowana przeze mnie audiodeskrypcja pozwala wykorzystać obraz do ćwiczeń językowych na wszystkich poziomach. Kierując się naczelną zasadą audiodeskrypcji, sugerującą opis elementów wizualnych w sposób wolny od interpretacji oraz subiektywnej opinii na ich temat, uczeń na początkowym etapie nauki może pracować z leksyką opisującą wygląd fizyczny postaci, ich wiek, ubiór, kolorystykę czy praktykować rozmieszczenie osób lub przedmiotów w przestrzeni. Wówczas, oprócz wprowadzenia nowej leksyki, w przygotowywanym przez ucznia skrypcie do obrazu zostają utrwalone również struktury gramatyczne. W grupach początkujących należy dobierać obrazy realistyczne, o wyrazistej formie i kolorystyce, które łatwo będzie zwerbalizować. W zależności od potrzeb dydaktycznych, można modyfikować wytyczne dotyczące profesjonalnej audiodeskrypcji obrazów. Do opisu wyglądu zewnętrznego oraz ubioru mogą posłużyć takie obrazy jak Mona Lisa lub Dama z gronostajem Leonarda da Vinci, Sulamitka Maurycego Gottlieba, Panny dworskie Diego Velázqueza, Portret nieznajomej kobiety Ivana Kramskoya czy Olgi w fotelu Pabla Picassa. Gwoli przykładu przytoczę fragment profesjonalnej audiodeskrypcji do obrazu Leonarda da Vinci Mona Lisa $^{7}$ :

Obraz przedstawia portret siedzącej młodej kobiety w ujęciu trzy czwarte. W tle zamglony górski krajobraz. Dominujące barwy to odcienie brązu, żółci, szarości i granatu. Kobieta zwrócona jest lekko w lewo. Wzrok kieruje w naszą stronę. Ciemnobrązowe włosy kobiety opadają na ramiona. Okrywa je półprzezroczysty welon. Pod nim na środku głowy przedziałek. Owalna twarz o jasnobeżowym kolorze. Czoło wysokie. Oczy mają migdałowaty kształt. Powieki bez rzęs, lekko przymrużone. Źrenice brązowe. Nos prosty. Jego płatki delikatnie zarysowane. Usta małe. Dolna warga uwydatniona.

\footnotetext{
${ }^{6}$ Szerzej o doborze materiału dopasowanego do potrzeb uczącego się w Szałasta-Rogowska, Bożena (2007).

${ }^{7}$ Fragment audiodeskrypcji pochodzi z audycji „Obrazy słowem malowane. Radiowe spotkania z audiodeskrypcją sztuk plastycznych, nie tylko dla najmłodszych”, Polskie Radio Białystok, Youtube, https://www.youtube.com/watch?v= JY79pwBnYiE. Autorami audiodeskrypcji są B. Szymańska, J. Sikora i M. Laskowski.
} 
W przypadku grup początkujących opis przygotowany przez ucznia w języku obcym zostanie uproszczony i dostosowany do jego możliwości. To samo ćwiczenie może być praktykowane w grupach bardziej zaawansowanych, dla których lektor może wybrać bardziej złożone i wymagające obrazy, w różnych stylach malarskich, na przykład obrazy kubistyczne (Panny z Awinionu, Guernica Pabla Picassa), obrazy impresjonistyczne (Śniadanie wioślarzy Auguste'a Renoira, Spacer brzegiem morza Joaquína Sorollego y Bastida) czy ekspresjonistyczne (Autoportret Edvarda Muncha czy Autoportret Vincenta van Gogha). Praca na zajęciach $\mathrm{z}$ audiodeskrypcją nie może zostać ograniczona do wyboru obrazu przez nauczyciela. Jego zadaniem jest dokładne zaplanowanie poszczególnych etapów lekcji - wprowadzenie właściwej leksyki, ćwiczeń gramatycznych, zapoznanie uczniów z audiodeskrypcją i jej głównymi zasadami, wcześniejsze zaplanowanie zadania $\mathrm{z}$ audiodeskrypcją, które może zostać przygotowane zgodnie $\mathrm{z}$ obowiązującymi standardami lub według wskazówek przygotowanych przez nauczyciela, a także przemyślenie końcowej fazy przygotowywania audiodeskrypcji, jaką jest nagranie gotowego skryptu. Do nagrania gotowej audiodeskrypcji można wykorzystać ogólnodostępne i bezpłatne aplikacje, które są łatwe w obsłudze ${ }^{8}$.

Nauczyciel może poprzestać na tak zaplanowanych etapach lekcji z wykorzystaniem audiodeskrypcji, ale również może dodatkowo zaplanować pytania do obrazu i jego audiodeskrypcji. Pytania mogą służyć przybliżeniu kontekstu historyczno-kulturowego rzeczywistości przedstawionej. Takim przykładem jest fragment profesjonalnej audiodeskrypcji do obrazu Francisca de Goi 3 maja 1808: Rozstrzelanie powstańców madryckich ${ }^{9}$ :

W mroku sączącym się z czarnego nieba, po lewej, na tle żółto-brązowo-szarego łagodnie opadającego ku prawej wzgórza, grupa skazańców, kilka ciał w szkarłatnych kałużach krwi. Postacie od dołu ostro oświetla blask skrzynkowej lampy, ustawionej pośrodku ziemi. Przed stojącym z prawej, osnutym cieniem odwróconym tyłem pięcioosobowym plutonem egzekucyjnym. Wycelowane w skazańców lufy karabinów skałkowych połyskują srebrzyście. Stojący w lekkim wykroku żołnierze armii napoleońskiej przesłaniają szkicowo narysowany tłum ludzi o zgarbionych plecach i twarzach zasłoniętych rękami.

Pytania mające na celu zgłębienie wiedzy historyczno-kulturowej mogą przybrać następujący kierunek:

Do jakich tragicznych wydarzeń mających miejsce w Hiszpanii nawiązał Goya?

\footnotetext{
${ }^{8}$ Na przykład Free Audio Editor, Audacity czy Subtitle Creator.

${ }^{9}$ Dostępna 12.06.2020 na stronie Fundacji Audiodeskrypcja: www.isztuka.edu.pl/i-sztuka/ node/467.
} 
Gdzie miały miejsce egzekucje przedstawione przez malarza?

Ile trwały walki powstańcze pomiędzy oddziałami Napoleona a hiszpańską ludnością cywilną?

Jakie emocje zostały uwiecznione przez artystę?

Jakie uczucia i emocje wywołuje w Tobie omawiany obraz?

W jakiej epoce tworzył Francisco de Goya?

Gdzie obecnie można podziwiać ten obraz?

Audiodeskrypcja dzieł sztuki rozpoczyna się od metryczki zawierającej ogólne informacje wprowadzające do przedstawionej na obrazie problematyki: tytuł dzieła, autor, data powstania, technika, w jakiej wykonano dzieło, oraz krótki opis tego, co przedstawia lub czego dotyczy (Szarkowska i Jankowska, „Zasady przygotowywania” 7). Elementy metryczki mogą również stanowić element ćwiczenia językowego, które jest realizowane ustnie poprzez pytania do przedstawionego obrazu. Ćwiczenie to może zostać przeprowadzone także $\mathrm{w}$ odwrotnej formie, $\mathrm{tj}$. nauczyciel bez pokazywania uczniom obrazu, prezentuje jego metryczkę. Zadaniem ucznia jest opowiedzenie, co znajduje się na obrazie o takim tytule lub wysunięcie hipotez, czego obraz może dotyczyć i w jakiej formie, kolorystyce, etc. został przedstawiony. W celu wprowadzenia elementów ludycznych, można wykorzystać audiodeskrypcję jako grę dydaktyczną. Nauczyciel powinien przygotować wcześniej audiodeskrypcję do wybranego obrazu, a następnie po przedstawieniu jej na zajęciach uczniowie powinni odwzorować obraz, rysując go zgodnie $\mathrm{z}$ opisem audiodeskryptywnym, lub przedstawić opisywaną scenę, na przykład poprzez upozowanie się zgodnie z wytycznymi zawartymi w prezentowanym skrypcie. Następnie nauczyciel powinien pokazać opisywany obraz i zaproponować do niego inne ćwiczenia językowe, polegające na znalezieniu synonimów lub antonimów do leksemów zawartych w przygotowanej wcześniej audiodeskrypcji, do wyrażenia opinii dotyczącej tekstu audiodeskryptywnego lub do stworzenia przez uczniów własnej autorskiej audiodeskrypcji, polegającej na subiektywnej interpretacji dzieła oraz wprowadzeniu bardziej poetyckich form opisu: metafory, porównania, epitetów etc. ${ }^{10}$

Inną metodą przekładu intersemiotycznego jest ekfraza, której celem jest twórcze zastąpienie i przywołanie obrazu poprzez własną formę poetycką.

${ }^{10}$ Elżbieta Gajek (172-173) proponuje ciekawe ćwiczenia z wykorzystaniem audiodeskrypcji do materiałów audiowizualnych, wśród których wymienia opis obrazka, rysowanie według wskazówek ustnych, audiodeskrypcję do meczu, audiodeskrypcję do fragmentów filmów udostępnionych na stronie ninateka.pl, opowiadanie filmu niewidomemu koledze, audiodeskrypcję autorską. 
Pomimo oczywistych podobieństw między audiodeskrypcją i ekfrazą, w których przypadku obserwuje się transpozycję uprzednich znaków wizualnych na znaki językowe, każdy z tych gatunków jest opisywany na potrzeby innej grupy odbiorców i ma inną specyfikę. Beata Jerzakowska, opisując różnice między audiodeskrypcją a ekfrazą, dochodzi do następujących wniosków:

obraz ma rdzeń fabularny, czyli skupia cztery jednostki składowe: sytuację (...), wydarzenie (...), akcję (...), bohatera (...). Jednak w audiodeskrypcji odesłanie do konkretnego dzieła sztuki jest zawsze jednoznaczne i nie stanowi rodzaju gry $\mathrm{z}$ odbiorcą. Audiodeskrypcja również nie jest formą wyobrażeniową, gdyż powstaje jako opis dla konkretnie istniejącego dzieła malarskiego, co zbliża ją do antycznego rozumienia pojęcia „ekfraza”.

(...) Wśród tropów wykorzystywanych w ekfrazach szczególnie można wymienić metaforę, metonimię, synekdochę oraz ironię. (343-344)

Wyszczególnione przez B. Jerzakowską tropy stosowane w ekfrazie, bardziej wymagająca forma opisu oraz abstrakcyjny charakter odwołujący się do emocji i doznań w kontakcie $\mathrm{z}$ dziełem, predysponują tę formę do pracy na zajęciach $\mathrm{z}$ grupami bardziej zaawansowanymi pod względem językowym. Ekfraza funkcjonuje jako intersemiotyczne dopełnienie obrazu, koresponduje z nim i dopełnia go. Teksty ekfrastyczne pisali Wisława Szymborska, Czesław Miłosz czy Stanisław Grochowiak. Rola lektora, tak jak w przypadku audiodeskrypcji, nie sprowadza się do wyboru obrazu, ale do starannego przygotowania faz lekcji z wykorzystaniem ekfrazy. Tak jak na zajęciach $\mathrm{z}$ audiodeskrypcją, na początku lektor powinien przygotować leksykę związaną z tematyką obrazu, a także zadania gramatyczne ukierunkowane na zagadnienia, które planuje on wprowadzić lub ćwiczyć. Ekfraza stwarza również możliwość wprowadzenia epitetów, porównań czy związków frazeologicznych. W ćwiczeniach przygotowujących można również wprowadzić formanty słowotwórcze, które pozwolą uczniowi na tworzenie nowych form leksykalnych i większą kreatywność. Inną możliwością jest wyszukanie na obrazie elementów-kluczy, wokół których będą rozwijane pola semantyczne. Bożena Szałasta-Rogowska proponuje również ćwiczenie, podczas którego uczący się opisze swoje skojarzenia lub odwoła się do własnych doświadczeń, a także kontaktu z przedmiotami codziennego użytku, które mogą stanowić element centralny wybranego obrazu (por. SzałastaRogowska 150). Kolejny etap powinien wiązać się z przedstawieniem ekfrazy, jej gatunku oraz charakterystycznych cech, a także warto zaprezentować uczniowi przykład tekstu ekfrastycznego, który równolegle będzie rozwijał jego wiedzę kulturową i wrażliwość emocjonalną. Warto na tym etapie 
podkreślić, że ekfraza jest wynikiem subiektywnych emocji i doznań, których uczeń doświadczył w kontakcie z dziełem, a intertekstualność, będąca wynikiem korespondencji sztuk, może mieć miejsce jedynie poprzez metatekstowe odniesienia w postaci nawiązania do artysty, tytułu, stylu malarskiego, gatunku lub przedstawionego na płótnie motywu. Kontakt z obrazem powinien być w tym wypadku dla ucznia inspirujący, rozbudzający jego wrażliwość estetyczną i emocjonalną oraz otwierający go na nowe formy literackie oraz sposoby ekspresji swoich emocji. Tym samym ekfraza stwarza możliwość formułowania wypowiedzi o charakterze abstrakcyjnym, emocjonalnym, wykorzystujących w sposób kreatywny język i ukazujących wrażliwość estetyczną, które trudno niejednokrotnie sprowokować na zajęciach z języka obcego. W związku z tym stworzenie przez ucznia ekfrazy nie powinno stanowić końcowego etapu pracy z obrazem. Lektor, poprzez pytania do ekfrazy, powinien prowokować uczącego się do dyskusji na temat emocji ewokowanych obrazem, które wiążą się z indywidualnymi cechami każdego z nas, a także z naszymi doświadczeniami. Warto również poszukać z uczniami miejsc wspólnych, które ukazują korespondencję między obrazem a stworzoną do niego ekfrazą. Ten motyw można wykorzystać w pracy z uczniami na niższych poziomach zaawansowania językowego, gdyż zadanie tym razem będzie polegało nie na napisaniu ekfrazy, a na analizie porównawczej obrazu i powstałego do niej tekstu ekfrastycznego. Przykładem takiej korespondencji testów jest Płonąca żyrafa Stanisława Grochowiaka oraz obraz hiszpańskiego surrealisty Salvadora Dalego o tym samym tytule, a także wiersz Wisławy Szymborskiej Dwie matpy Bruegla do obrazu Pietera Bruegla Dwie matpy czy Stanisława Grochowiaka Otwarcie mroku, który koresponduje z obrazem Francisca de Goi Gdy rozum śpi, budza się potwory. Celem ćwiczenia jest pokazanie uczącemu się różnych rejestrów i stylów języka, a także różnych form (wizualnych i werbalnych) przekazywania treści.

Jeszcze inną formę pracy z metodą przekładu intersemiotycznego może stanowić infraza. Należy w tym miejscu podkreślić, że infraza nie jest tożsama z ilustracją obrazującą tekst, ale jest odbiciem emocji wywołanych lekturą. Ten rodzaj ćwiczeń bywa wykorzystywany najczęściej jako środek dydaktyczny $\mathrm{w}$ pracy $\mathrm{z}$ młodszymi uczniami, którzy rysując lub malując przedstawiają treść utworu.

Wybór teksu literackiego lub jego fragmentu (może to być również piosenka) jest pierwszym etapem podjętych przez nauczyciela działań i jest on warunkowany zaplanowaną tematyką lub zagadnieniami gramatycznymi. Następnie nauczyciel powinien przygotować ćwiczenia leksykalne 
i gramatyczne na podstawie tego tekstu. Mogą to być ćwiczenia polegające na szukaniu synonimów, antonimów, na wstawianiu brakujących leksemów z kontekstu, na tworzeniu pól semantycznych, zadania ze słowotwórstwa, tworzenia definicji do leksemów z wykorzystaniem konotacji i denotacji uczącego się, odtworzeniu związków przyczynowo-skutkowych poprzez pracę $\mathrm{z}$ fragmentami tekstu, które należy ułożyć we właściwym porządku, sparafrazowaniu fragmentów tekstu, ćwiczenia polegające na zmianie stylu wypowiedzi z wysokiego na kolokwialny etc. Po ćwiczeniach językowych, które miały ułatwić lekturę tekstu i jego zrozumienie, lektor rozpoczyna pracę z analizą utworu, której efektem ma być wyrażenie indywidualnych odczuć i doznań uczącego się w postaci reprezentacji wizualnej. Infraza nie musi być malarską reprezentacją, może przybrać formę zdjęcia lub kolażu. $\mathrm{Na}$ ostatnim etapie należy wyegzekwować od ucznia wypowiedź argumentującą jego pracę. Jako przykład mogą posłużyć teksty piosenek Jacka Kaczmarskiego i inspirowane nimi obrazy Stanisława Jerzego Dołyżyka czy już wspomniane teksty Wandy Karczewskiej i reprezentujące je grafiki Krzysztofa Schodowskiego.

Praca na zajęciach z infrazą może zniechęcać nauczycieli, gdyż panuje przekonanie, że starsze grupy niechętnie posługują się rysunkiem jako środkiem dydaktycznym. Warto jednak podkreślić wagę różnorodności metod aktywizujących lewą i prawą półkulę mózgu, których współdziałanie ma duży wpływ na przyswajanie języka obcego ${ }^{11}$. Język jest systemem złożonym, składającym się z kilku płaszczyzn: fonologicznej, morfologicznej, syntaktycznej, semantycznej i pragmatycznej. Dlatego niezwykle ważne jest pobudzanie na zajęciach lewej i prawej półkuli, które umożliwią uczącemu się postrzeganie języka w sposób holistyczny. Zdaniem Ewy Kusideł:

Mowa jest kontrolowana przez lewą półkulę i dzięki niej konstruujemy i rozumiemy nawet wyszukane konstrukcje zdaniowe. Prawa półkula ma tu też swoje zadanie: to ona rejestruje takie cechy wypowiedzi, jak melodia, rytm i intonacja która może całkowicie zmienić sens zdania.

(...) Poeta dzięki prawej półkuli ma natchnienie i widzi ogólny zarys poematu, lecz jego lewa półkula ubiera te przeżycia w słowa. Artysta tworzy wizję obrazu w prawej półkuli, lewa jest mu natomiast potrzebna do dobrania właściwych proporcji farb, aby uzyskać pożądane barwy. (89-90)

Wnioski badaczki bezpośrednio korespondują z zaproponowaną w tekście metodą nauczania języka poprzez przekład intersemiotyczny. To dzięki

${ }^{11}$ Badania dotyczące wpływu półkul na nauczanie językowe omawia Merve Oflaz w swoim artykule The effect of right and left brain dominance in language learning. 
transpozycji obrazu na słowo (audiodeskrypcja, ekfraza), a także tekstu na jego reprezentację wizualną (infraza), uczeń pobudza tak lewą, jak i prawą półkulę, co wpływa na efektywniejsze przyswajanie języka oraz zapamiętywanie. Dlatego też, aby opanować leksykę i gramatykę, w końcu język, który jest złożonym systemem, konieczne jest wykorzystanie wszystkich możliwości mózgu.

\section{PODSUMOWANIE}

Nauczanie poprzez sztukę, zwłaszcza reprezentowaną przez obrazy i teksty literackie, stwarza wiele możliwości dydaktycznych, których namiastkę starałam się w tekście pokazać. Sztuka na zajęciach lektoratowych pozwala przezwyciężyć rutynę i ułatwia proces przyswajania języka. Ponadto jest autentycznym materiałem dostarczającym wiedzy historyczno-kulturowej, tak ważnej w nauce obcego języka. Jest pretekstem do formułowania osobistych sądów uczącego się. Rozwija wyobraźnię, pobudza do kreatywnego działania i używania języka. Zaproponowana w tekście metoda przekładu intersemiotycznego uczy transpozycji kodów pozawerbalnych na werbalne i odwrotnie. Uwrażliwia na sztukę, prowokuje do poszukiwania nowych form wyrażania emocji, poszerza słownictwo, pozwala na praktykowanie i utrwalenie poprawnych struktur gramatycznych oraz - co równie istotne - do artykułowania własnych emocji i doznań wywołanych kontaktem ze sztuką obrazową i literacką.

\section{BIBLOGRAFIA}

Calduch, Carme, i Noa Talaván. „Traducción audiovisual y aprendizaje del español como L2: el uso de la audiodescripción". Journal of Spanish Language Teaching, t. 4, issue 2, 2018, ss. 1-13.

Chmiel, Agnieszka, i Iwona Mazur. Audiodeskrypcja. Wydział Anglistyki UAM, 2014.

Clouet, Richard. „Estrategia y propuestas para promover y practicar la escritura creativa en una clase de inglés para traductores" (2005). Actas del IX Simposio de Internacional de la sociedad española de didáctica de la lengua y la literatura, SEdll, sedll.org/es/ congresos_actas interior.php?cod=33. Dostęp 15.05.2019,

Dyduchowa, Anna. Metody kształcenia sprawności językowej uczniów. Projekt systemu, model podręcznika. Wydawnictwo Naukowe WSP, 1988.

Dziadek, Adam. Obrazy i wiersze. Z zagadnień interferencji sztuk w polskiej literaturze wspótczesnej. Wyd. II. Wydawnictwo Uniwersytetu Śląskiego w Katowicach, 2011.

Fundacja Audiodeskrypcja, www.isztuka.edu.pl/i-sztuka/node/467. Dostęp 12.06.2020. 
Gajek, Elżbieta. „Tłumaczenie audiowizualne w dydaktyce języków obcych - na przykładzie audiodeskrypcji”, red. Lipińska Ewa i Anna Seretny, Tlumaczenie dydaktyczne w nowoczesnym kształceniu językowym, Biblioteka LingVariów, t. 12, Uniwersytet Jagielloński. Wydział Polonistyki, ss. 165-179.

Ibáñez Moreno, Ana, i Anna Vermeulen. „La audiodescripción como recurso didáctico en el aula de ELE para promover el desarrollo integrado de competencias", New Directions on Hispanic Linguistics, red. Orozco Rafael, Cambridge Scholars Publishing, 2014, ss. 264-292.

Ibáñez Moreno, Ana, i Anna Vermeulen. „Audio Description as a Tool to Enhance Intercultural Competence". Towards Transcultural Awareness in Translation Pedagogy, red. Deconinck Julie, Phillipe Humblé, Arvi Sepp i Hélène Stengers, LIT Verlag, 2017, ss. 133-156.

Ibáñez Moreno, Ana, Anna Vermeulen i Maria Jordano. „Using audio description to improve FLL students' oral competence in MALL: methodological preliminaries". New perspectives on teaching and working with languages in the digital era, red. Pareja Lora, Antonio, Cristina Calle Martínez i Pilar Rodríguez Arancón, Research-publishing.net, 2018, ss. 245-256.

Jakobson, Roman. „O językoznawczych aspektach przekładu”. Tłum. L. Pszczołkowska, 1959. Współczesne teorie przekładu, red. Bukowski Piotr i Magdalena Heydel, Antologia, Znak, 2009, ss. 41-49.

Jerzakowska, Beata. Audiodeskrypcja malarstwa - wyznaczniki gatunku i ich realizacje tekstowe. Niepublikowana rozprawa doktorska .. Uniwersytet Adama Mickiewicza w Poznaniu, repozytorium.amu.edu.pl/bitstream/10593/23553/3/ B\%20 Jerzakowska_Audio deskrypja _malarstwa_wyznaczniki_gatunku_i\%20_ich_realizacje_tekstowe.pdf. Dostęp 10.09. 2018.

Kaczmarczyk, Katarzyna. Narratologia transmedialna. Teorie, praktyki, wyzwania. Universitas, 2017.

Kaźmierczak, Marta. „Od przekładu intersemiotycznego do intersemiotycznych aspektów tłumaczenia”. Przektadaniec, nr 34, 2017, ss. 7-35.

Kroeber-Riel, Werner. Bildkommunikation. Imagery-Strategien für die Werbung. München Vahlen, 1993.

Kusideł, Ewa. „Rola neuropsychologii w nowoczesnym nauczaniu”. Acta Universitatis Lodziensis. Folia Oeconomica, nr 217, 2008, ss. 87-97.

Oflaz, Merve. "The effect of right and left brain dominance in language learning". Procedia Social and Behavioral Sciences, vol 15, Elsevier, 2011, ss. 1507-1513.

Opiłkowski, Roman, Józef Jarosz i Przemysław Staniewski. Lingwistyka mediów. Antologia thumaczeń. ATUT/Neisse Verlag, 2015.

Radziewicz, Teresa. „Od ekfrazy do infrazy”, Logos - filozofia słowa. Szkice o pograniczach języka, filozofii i literatury, red. Andruczyk Krzysztof, Ewa Gorgolewska i Krzysztof Korotkicha, Uniwersytet w Białymstoku. Wydział Filologiczny. Instytut Filologii Polskiej, 2017, ss. 167-181.

Słodczyk, Rozalia. „Analiza interartystyczna ekfraz: Lekcja muzyki Vermeera w interpretacji Adama Zagajewskiego i Joanny Pollakówny”. Slavia Occidentaalis, t. 74, nr 2, 2017, ss. 17-37.

Szałasta-Rogowska, Bożena. „Tekst literacki i malarski w nauczaniu cudzoziemców. Sposoby pracy na zajęciach lektoratowych", Sztuka czy rzemiosło? Nauczyć Polski i polskiego, red. Aleksandra Achtelik i Jolanta Tambor, Wydawnictwo Uniwersytetu Śląskiego, 2007, ss.141-152. 
Szarkowska, Agnieszka, i Jankowska Anna. „Zasady przygotowywania treści przewodnika multimedialnego". Wersja 2. 2015. AVTLab, www.avt.ils.uw.edu.pl. Dostęp 10.05.2020.

Szarkowska, Agnieszka, Anna Jankowska i Krzysztof Krejtz. „Open Art. - desinging a multimedia guide app for people with and without sensory impairments", 2015. Open Art, openart. ibemag.pl/images/publikacje/SzarkowskaJankowska ARSAD2015.pdf. Dostęp 10.05.2020.

Szymańska, Barbara, i Tomasz Strzymiński. „Standardy tworzenia audiodeskrypcji do produkcji audiowizualnych", 2010. AVTLab, avt.ils.uw.edu.pl/files/2010/12/AD- standardy tworzenia.pdf. Dostęp 2.04.2020.

Szymańska, Barbara. „Audiodeskrypcja. Obraz słowem malowany”. Youtube, www.youtube.com/ watch?v=JY79pwBnYiE. Dostęp 23.05.2020.

Szymik, Eugeniusz. „Metoda przekładu intersemiotycznego w edukacji wczesnoszkolnej”. Pedagogika Szkolna i Wczesnoszkolna, t. 5, nr 1 (9), 2017, ss. 111-120.

Talaván Zanón, Noa. „Creative Audiovisual Translation Applied to Foreign Language Education: A preliminary approach”. Journal of Audiovisual Translation, t. 2, nr 1, 2019, ss. 53-74.

Wysłouch, Seweryna. Literatura i semiotyka. Wydawnictwo Naukowe PWN, Warszawa, 2001.

\section{NAUCZANIE GRAMATYKI I LEKSYKI POPRZEZ SZTUKĘ. EKFRAZA, INFRAZA I AUDIODESKRYPCJA NA LEKCJI JĘZYKA OBCEGO}

\section{Streszczenie}

Korespondencja sztuk oraz intersemiotyczny dialog, w którym biorą udział teksty literackie oraz płótna malarskie, stwarzają nowe możliwości w nauczaniu języków obcych. Ekfraza oraz infraza dążą do subiektywnej reprezentacji tekstu malarskiego i odpowiednio literackiego, próbując go zastąpić oraz uczynić obecnym w nowym znaku. Podobne zadanie do spełnienia ma audiodeskrypcja, która poprzez obiektywny opis tekstów wizualnych ma je uobecnić, ożywić i udostępnić osobie niewidomej. Zarówno ekfraza, infraza, jak i audiodeskrypcja są wynikiem kreatywnej transpozycji i interpretacji towarzyszącej przekładowi intersemiotycznemu, którego dokonuje uczeń na lekcji języka obcego. Każda z wymienionych reprezentacji i każdy kontakt ze sztuką oferują liczne korzyści na lekcji języka obcego. Oprócz korzyści językowych, takich jak sposobność do ćwiczenia struktur gramatycznych, wprowadzenia nowego słownictwa, rozwijania kompetencji komunikacyjnej oraz interkulturowej, wart podkreślenia jest również wymiar neurodydaktyczny sztuki na lekcji języka obcego.

Słowa kluczowe: literatura; sztuka; metoda przekładu intersemiotycznego na lekcji języka obcego; ekfraza; infraza; audiodeskrypcja.

\section{TEACHING GRAMMAR AND LEXIS THROUGH ART: EKPHRASIS, INPHRASIS AND AUDIO DESCRIPTION DURING A FOREIGN LANGUAGE LESSON}

S u m mary

The correspondence between art and the intersemiotic dialogue in which literary texts and paintings are involved creates new possibilities for the teaching of foreign languages. Both ekphrasis and its contrastive inphrasis tend to subjectively represent paintings and literary texts, while trying to replace them and reveal their presence as a new symbol. Audio description plays 
a similar function - through an objective description of visual texts, it aims to make them livelier, more present, and more accessible to a blind person. Ekphrasis, inphrasis and audio description exist as a result of the creative transposition and interpretation which accompany the intersemiotic translation. This process is conducted by the student. Each of the representations mentioned, and every contact with art, offers many benefits during foreign language classes. Apart from linguistic benefits, such as gaining an additional opportunity to practice grammatical structures, introducing new vocabulary, and developing communication and intercultural skills, it is also important to note the neurodidactic aspect of art while conducting a foreign language lesson.

Keywords: literature; art; intersemiotic translation in a foreign language class; ekphrasis, inphrasis; audio description. 